\title{
Management Model of Village Fund Allocation in Enhancing the Village's Productive Economic
}

\author{
Activities \\ Imran Rosman Hambali (Corresponding author) \\ Faculty of Economics, Universitas Negeri Gorontalo, Gorontalo, Indonesia \\ Email: imranrh2012@yahoo.co.id
}

Idris Yanto Niode

Faculty of Economics, Universitas Negeri Gorontalo, Gorontalo, Indonesia

\author{
Received: August 11, 2018 Accepted: August 31, 2018 Published: September 18, 2018 \\ doi:10.5296/ber.v8i4.13489 URL: https://doi.org/10.5296/ber.v8i4.13489
}

\begin{abstract}
The study aims to elaborate the management and allocation of village fund from the central and local governments and to formulate management model and documents of strategic plans in the implementation of the fund in the second year as a follow-up development.

The research involved village heads and officers in Regional Government of Bone Bolango regency, local public figures, and residents receiving financial support from the village fund. The descriptive qualitative study employed Milles and Huberman analysis method and conducted focus group discussions to obtain the data.

The result shows that the implementation of the management model is successful to empower the community, as overviewed from achievements by the Regional Government of Bone Bolango regency. The government's achievement inspires the central government to allocate more fund to the village in the next year. The village fund of IDR 122,344,494,000 is distributed as follows: $30 \%$ of the fund is allocated for the operational budget of the village government and the Village Consultative Body (Badan Permusyawaratan Desa, BPD); moreover, $70 \%$ of the fund is distributed for empowerment of the community and enhancement of the village government's capacity. Henceforth, it is proven that the village fund is optimally conducted as economic leverage for the village to progress and as a helping hand to boost the community's welfare in Bone Bolango regency.
\end{abstract}

Keywords: Management model of village fund allocation (add), Productive economy 
activities

\section{Introduction}

As a part of the implementation of regional autonomy, Village Fund Management is a program by the local government to achieve the set goals and strategic plans employed through various activities. As stipulated in the Government Regulations no. 72 of 2005 concerning village management, the administration of village government affairs under the authority of the local government is funded from the Village Budget and Village government Aid. It is also in accordance with the Letter of Ministry of Internal Affairs no. 140/640SJ on March 22, 2005, concerning Guidelines for Village Fund Allocation from the Regional Government to the village government; and the Regulation of Ministry of Internal Affairs no. 37 on 2007 concerning Guidelines for Village Fund Management. As written in Article 68 of the Government Regulation no. 72 of 2005 , the village is allowed to receive funds from the Regional Tax Share and Retribution as well as some part of Central and Regional Financial Balance Fund accepted by the Regional Government. The village fund from the regional government is distributed through the village cash, complying with the Article 2A of Act 34 of 2000 concerning changes in Act 28 of 2009 concerning Local Tax and Retribution.

On top of that, as regulated in Act 6 of 2014 concerning Village, the village is granted authority to administer governance and development independently to enhance the community's welfare and life quality. With that being said, the village government is expected to conduct independent governance for its resources, including the village's finance and wealth. Such big contribution the village possesses also comes with big responsibility to bear. Therefore, it is essential for the village to implement principles of accountability in governance, ensuring that the activities and village governance are able to be accounted to the public by referring to the applied rules.

Moreover, the village government is required to involve the community in processes of planning, budgeting, and implementing government programs, facilitated through the decision-making process in village conference by Village Consultative Fund (BPD). The involvement is expected to result in a work program and activity that accommodate the community's interest and needs inclusively, and suitable for the community capability.

The sectoral development in the village that utilizes village fund allocation is crucial and strategic to the national development and regional economy enhancement. Based on the local regulation concerning Village Fund Allocation, the allocation of the village fund is distributed as follows: $30 \%$ from the fund is used for operational budget, allowances, and official travel expenses, while $70 \%$ is employed in community empowerment and capacity enhancement of the village governments. The allocation is critical to be implemented optimally by the village governments to achieve the set goals and targets.

By the village fund allocation, the Government of Gorontalo province strives to empower developers and provide programs of increasing productive economic activities by maximizing the facilities and financial aids from the central government. This way, the village can contribute to the regional development. With that being said, a description of the management 
of village fund allocation is essential to conduct, in which the study focuses on the management of village funds in Bone Bolango regency.

Based on the previous description, and as a development of findings of preliminary research in 2017 , this research intends to answer the questions:

1. How is the actual condition of activities of community empowerment and productive economy enhancement by Village Fund and Village Fund Allocation?

2. How are the strategic plans of developing management model of Village Fund and Village Fund Allocation in increasing the community's welfare and empowerment?

\section{Literature Review}

\subsection{Concepts of Village Government}

Definition of the village by Act 22 on 1999 is a village, or as called with another term, as a union of a legal society which has its original structure referring to special privileges of origin, as stipulated in Article 18 of 1945 Basic Constitution (Bratakusumah \& Solihin, 2003: 8). The ideological foundations in the governance of the village government diversity, participation, indigenous autonomy, democracy, and community empowerment.

Moreover, as written in Government Regulations No. 60 of 2014, a village includes village, traditional village, or as called with another term, further referred as village, is a union of legal community with territorial boundaries and authority to regulate and administer government affairs, the interests of local communities based on community initiatives, origins rights, and/or traditional rights recognized and respected within the system of government of Republic of Indonesia.

\subsection{The Concept of Village Fund and Village Allocation Fund}

Eko et al. (2006: 1) state that Village Fund is the fund from the State Budget distributed to the village through Regional Budget of regency/city in every year. It is granted to fund the village governance based on origin rights and village-scale local authority.

The fund is a mandate of Act 6 of 2014 concerning village, allocated in the transfer, not as a project. As long as the law applies, the fund will be distributed continuously.

\subsection{Position and Function of Village Fund}

As a main financial source, Village Fund is utilized in programs and prioritized activities set in the village's forum on deliberation of development planning (Musrembang Desa) discussing the village government work plan in every year. The use of Village Funds in self-management or labor-intensive manner aims to increase employment in the village, especially for the low-income family; and provision of basic village infrastructure, such as environmental roads, farm roads, bridges, and irrigation channels.

According to Act 6 of 2014, Village Fund is the fund from State Budget allocated to villages that are distributed through the Regional Budget; it is used to finance the administration, implementation, development, community development, and community empowerment of 
the village.

According to the Regulation of Ministry of Internal Affairs No.37 of 2007 concerning Guidelines of Village Budget Management, Village Fund Allocation is aimed at:

1. Addressing poverty and reducing inequality;

2. Improving village level development planning and budgeting, and community empowerment;

3. Increasing rural infrastructure development;

4. Encouraging the implementation of religious and socio-cultural values in order to achieve social improvement;

5. Enhancing public order and peace;

6. Improving services to rural communities as a form of social and economic development

7. Encouraging the improvement of self-help and mutual cooperation between the community;

8. Increasing income of the village and the community through Village Owned Enterprise (BUMDesa).

\section{4 Village Fund Allocation Management}

As an integral part of village budget management, the management of Village Fund Allocation is required to meet the principles as follows:

a. All activities funded by Village Fund Allocation are planned, implemented and evaluated openly with the principles of, by and for the community.

b. All activities must be accountable administratively, technically and legally.

c. Village Fund Allocation (ADD) is carried out using the principles of financially efficient, focused, and controlled.

d. All activities that will be financed through Village Fund Allocation must contribute to improving community service facilities, i.e., fulfillment of basic needs, strengthening village institutionalization and other essential activities the village community decided in forums.

e. Village Fund Allocation must be recorded in the Village Budget (APBDesa), and the budgeting process follows the applied mechanism.

\subsection{Community Empowerment}

Supeno (2011:19) empowerment is an effort towards an order made by elements from outside the order, so that the order is able to develop independently; in other words, empowerment is an effort to improve interconnection in an order and/or refinement of the elements/components of the order to enhance the order's independence development.

\section{Research Method}

Based on the previous problems statement, the study employed descriptive qualitative method. Moreover, the data collection involved interview and Focus Group Discussion (FGD). The research object encompassed 160 villages and five sub-districts in Bone Bolango regency. The study focused its analysis on the village in order to identify different approaches of 


\section{Macrothink}

Business and Economic Research ISSN 2162-4860 2018, Vol. 8, No. 4

Village Fund Allocation management in the villages as an effort of productive economy empowerment of the community.

\section{Findings and Discussion}

\subsection{Village Fund and Village Allocation Fund in 2017}

As a source of income, APBDes or Village Budget is categorized into 1) Funds from State Budget allocated to the village by direct transfer through Regional Budget of city/regency; 2) Village Fund Allocation from the regency/city in the form of revenue sharing funds and general allocation funds, as a part of balancing funds.

The following is the table of distribution of Village Funds and Village Funds Allocation of 2017 in Bone Bolango regency.

Table 1. Distribution of Village Funds and Allocation of Village Funds of 2017 in Bone Bolango regency

\begin{tabular}{|l|l|l|l|l|l|}
\hline No. & District & $\begin{array}{l}\text { Village Fund } \\
\text { Ceiling }\end{array}$ & $\begin{array}{l}\text { Village Fund } \\
\text { Allocation Ceiling }\end{array}$ & $\begin{array}{l}\text { Affirmative Village } \\
\text { Fund Allocation Ceiling }\end{array}$ & Total \\
\hline 1 & Tapa & $5,332,740,000$ & $2,113,251,000$ & & $7,445,991,000$ \\
\hline 2 & Kabila & $5,330,520,000$ & $2,108,145,000$ & & $7,438,665,000$ \\
\hline 3 & Suwawa & $7,621,352,000$ & $3,008,718,000$ & & $10,630,070,000$ \\
\hline 4 & Bone Pantai & $9,982,737,000$. & $3,985,881,000$ & & $13,968,618,000$ \\
\hline 5 & Bulango Utara & $6,866,424,000$ & $2,711,931,000$ & & $9,578,355,000$ \\
\hline 6 & Tilongkabila & $10,718,446,000$ & $4,257,138,000$ & & $14,975,584,000$ \\
\hline 7 & Botupingge & $6,730,321,000$ & $2,640,447,000$ & & $9,370,768,000$ \\
\hline 8 & Kabila Bone & $7,046,338,000$ & $2,860,005,000$ & 488.250 .000 & $10,394,593,000$ \\
\hline 9 & Bone & $10,733,449,000$ & $4,241,820,000$ & & $14,975,269,000$ \\
\hline 10 & Bone Raya & $7,576,269,000$ & $2,983,188,000$ & & $10,559,457,000$ \\
\hline 11 & Suwawa Timur & $6,834,360,000$ & $2,691,507,000$ & $488,250,000$ & $10,014,117,000$ \\
\hline 12 & Suwawa Selatan & $6,146,537,000$ & $2,450,886,000$ & & $8,597,423,000$ \\
\hline 13 & Suwawa Tengah & $4,553,635,000$ & $1,796,040,000$ & & $6,349,675,000$ \\
\hline 14 & Bulango Ulu & $4,626,776,000$ & $1,811,358,000$ & $976,500,000$ & $7,414,634,000$ \\
\hline 15 & Bulango Selatan & $7,725,521,000$ & $3,064,884,000$ & & $10,790,405,000$ \\
\hline 16 & Bulango Timur & $3,790,462,000$ & $1,494,147,000$ & & $5,284,609,000$ \\
\hline 17 & Bulawa & $6,824,388,000$ & $2,706,825,000$ & & $9,531,213,000$ \\
\hline 18 & Pinogu & $3,894,228,000$ & $1,580,999,620$ & $600,008,980$ & $6,075,236,600$ \\
\hline Total Amount & $\mathbf{1 2 2 , 3 3 4 , 5 0 3 , 0 0 0}$ & $\mathbf{4 8 , 5 0 7 , 1 7 0 , 6 2 0}$ & $\mathbf{2 , 5 5 3 , 0 0 8 , 9 8 0}$ & $\mathbf{1 7 3 , 3 9 4 , 6 8 2 , 6 0 0}$ \\
\hline
\end{tabular}

Source: Office of Village and Community Empowerment, and Village government 2017

As the table illustrates, the average total amount of funds managed by every village in Bone 
Bolango regency is IDR 1.000.000.000,- by the minimum.

\subsection{Model of Village Fund Management and Village Fund Allocation}

\subsubsection{Planning of Village Fund Management and Village Fund Allocation}

As a preliminary step of Village Fund management, the planning process involves aspirations from lower strata community. This is to obtain data of the community's prioritized needs.

The step begins with forums conducted in the village to formulate the following programs, i.e., Medium-Term Development Plan (RPJMDes), Development Work Plan (RKPDes), and Village Budget (APBDes). The programs are legally protected by regulations by the village government. Thus, it is considered that the planning process has involved the community participation.

Moreover, Adisasmita (2006: 28) mentions that the participative planning process must be carried out through problem analysis, analysis of potential, and analysis of group interests within the community. The analysis requires measurable criteria in order to result in development programs that comply with the community's prioritized needs. By that, the planning process is conducted bottom-up by involving participative and spatial approach.

\subsubsection{Village Fund Budgeting}

The budgeting process of Village Fund is employed when the forum has reached an agreement of Village Fund Planning; by that, the forum can progress to formulate Fund Utilization Plan $(R P D)$ for one year. The interview result with the village leaders indicates that funds allocated for community empowerment and government capacity enhancement do not conform to the operational budget of the government and Village Consultative Bodies. The gap is identified in the firstly conducted village-level forum.

As observed from budget distribution, the budget of community empowerment and government capacity enhancement is much bigger compared to the operational budget for the government and Village Consultative Body. This is due to the prioritization of community empowerment and government capacity enhancement based on the forum's considerations.

Eko et al. (2016: 18) state that: Firstly, the use of village funds for village development and community empowerment is an integral part of national development equity; in order that the Village Fund fulfills the needs of the community and contributes to reducing poverty and inequality. Secondly, the prioritization of Village Fund is in accordance with national priorities as in NAWACITA, i.e., infrastructure, food, energy, and village enhancement as a form of outside-in development. Thirdly, the government's effort of empowering village is aimed for the village stakeholders to not only contribute to government administration but to also participate in providing tangible benefits to the community through development and empowerment.

\subsubsection{Village Fund Disbursement}

Technically, disbursement and distribution process of Village Fund and Village Fund Allocation is principally similar. This process starts from the village level, in which the 
village government (represented by the village treasurer) must complete all the files required for village funds application. When the application file is complete, it is then submitted to the District Office for preliminary verification. Moreover, the submitted file progresses to the Office of Village Empowerment and Governance, under the supervision of the Head of District. Furthermore, the file (including its attachments) is forwarded by the Office to the head of the Office of Income, Financial, and Asset Management (DPPKA). If all requirements have been met, then the Office will disburse the Village Fund and Village Fund Allocation to each village's bank account.

The process is obtained from an interview with Ms. Anisa Hubulo, SE. (The treasurer of Southern Talulobotu village), the interview quote is as follows:

"In the application of Village Fund or Village Fund Allocation, we (the stakeholders) has prepared required files and submitted to the District to be verified. Then the file is forwarded to the Office of Village Empowerment and Governance for advanced verification, moreover, the file is progressed to the Regional Office of Income. When the requirements have been completed and fulfilled, we only wait for the payment order and transfer to our bank account."

\subsubsection{Village Fund and Village Fund Allocation Utilization}

As stipulated in Act 6 of 2014 concerning Village, the village is allowed to govern administrative affairs, development, community empowerment, and community fostering. This is to say that all income sources, including Village Fund from State Budget, are utilized in financing the village administration. However, as the Government Regulation No. 60/2014 stipulates that Village Fund is from State Budget, therefore, to utilize the fund optimally, the Government is given authority to prioritize the fund to support development and community empowerment, but still relevant to the responsibility under the village government.

Specifically, the use of village fund allocation (ADD) is for two purposes, i.e., for the implementation of village governance and community empowerment. The former is implemented in Stakeholder Allowance (TAPDes), government operational budget, and operation of the Village Consultative Body. On the other hand, the latter is allocated in public infrastructure building/maintenance, capacity enhancement of the village's civil institution, economy enhancement, and aids in Village Consultative Body and Village Head election.

Based on the previous description, the Government of Bone Bolango regency implements community empowerment programs funded by Village Funds and Village Funds Allocation, as follows:

1. Cattle-breeding business

The government provides livestock aid, in which every low-economic household receives two cows, to be rotated to another household in the second year. Aside from that, the community receives free-range chicken.

2. Karang Taruna (Youth Organization)

The aid takes the form of the capital aid of vehicle workshop equipment and others.

3. Agricultural Business 
Type of agricultural assistance is the procurement of corn seeds and superior rice seed varieties, and fertilizer assistance.

4. Fishery Business

The assistance provided in this scope is the procurement of fishing boats and equipment. In freshwater fishery, the assistance provided is the procurement of tilapia fish, catfish, and prawn seeds.

5. Industrial Business

The assistance provided is the aid of capital and equipment.

6. Women-oriented Business

The assistance provided is the procurement of ginger seeds, chili seeds, and stock of goods for stalls and kiosks, and others.

Aside from the previous assistance, the government also provides coaching and mentoring programs related to the assistance. For instance, besides assistance of livestock, the household is given training in giving nutritious food to the animal.

However, there are several matters of concern in the use of the funds. There are financing activities prohibited from utilizing the Village Fund, such as village officials' allowances, official travel, village office construction, renovation, and procurement of furniture. Moreover, empowerment programs such as PKK program, mosque clerics' allowances and mosque keeper allowances is prohibited from using the Village Fund. Consequently, activities not funded by Village Fund is included in the prioritization of Village Fund Allocation.

As an effort to optimize village funds, capital assistance was provided by the Empowerment Office and the village governmentto business actors in accordance with the strategic objectives formulated. Furthermore, community economic development is implemented through PROKADES (Village's main commodity) through the development of OVOP (One Village One Product).

The results of the program can be seen from the superior commodities by each village. For example, Mongiilo village is famous for palm sugar, Pinogu Village has Pinogu coffee, Panggula Village with curuti cake (egg roll cake), and Tupa Village, which is famous for its honey products.

\subsubsection{Village Fund Monitoring and Evaluation}

In local scale, the Village Law affirms the right of the Village Consultative Body (BPD) to supervise and request information about the administration of the village government, including financial record. Furthermore, monitoring the flow of village funds carried out by the BPD discusses the strategic use of village funds in addressing problems.

This is in accordance with an explanation of Mr. Mahdi Yusuf (Head of Village Consultative Body of Southern Talulobutu village). He claims that BPD does not only conduct supervision but also encourages the village governmentto take responsibility for the management and disbursement of village funds. The interview quote is as follows:

“As BPD, we must be involved in the monitoring system as our responsibility. It is due to 
our participation in signing the budget proposal."

Community involvement is highly expected to participate in the supervision of the use of village funds in development in accordance with village regulations. The community also has the rights to obtain information on the implementation of activities financed from the village funds.

Further, to avoid undesirable things such as misuse of village budget, the finance is managed by the village stakeholders, i.e., Village Head, Village Secretary, Head of Village Affairs, and Treasurer, each of whom has different authorities, duties, and responsibilities. This is done to ensure that the financial control of the Village is not handled by a single person, but by a team with a governance system in order to detect any misuses.

\subsubsection{Accountability}

The village government, in this case, Village Head and stakeholders, is required to submit an accountability report at the end of the year. Accountability report is submitted and reported in the village forum, in which the forum also conducts development planning for next year.

This is in line with an interview with Ms. Indrawaty Lasia (Head of Lomaya village) as follows:

"The accountability process is carried out during each activity through documentation and report document. Furthermore, the report is submitted to the Village Community Empowerment Agency, the BPD, and Regent". (Interview, August 18, 2017)

The previous statement signifies that the administration of financial accountability of the Village Fund Allocation program in Bone Bolango regency has implemented accountability principles.

The following Figure 1 is a management model of Village Fund and Village Fund Allocation in increasing productive economic activities developed by this study: 


\section{I Macrothink}

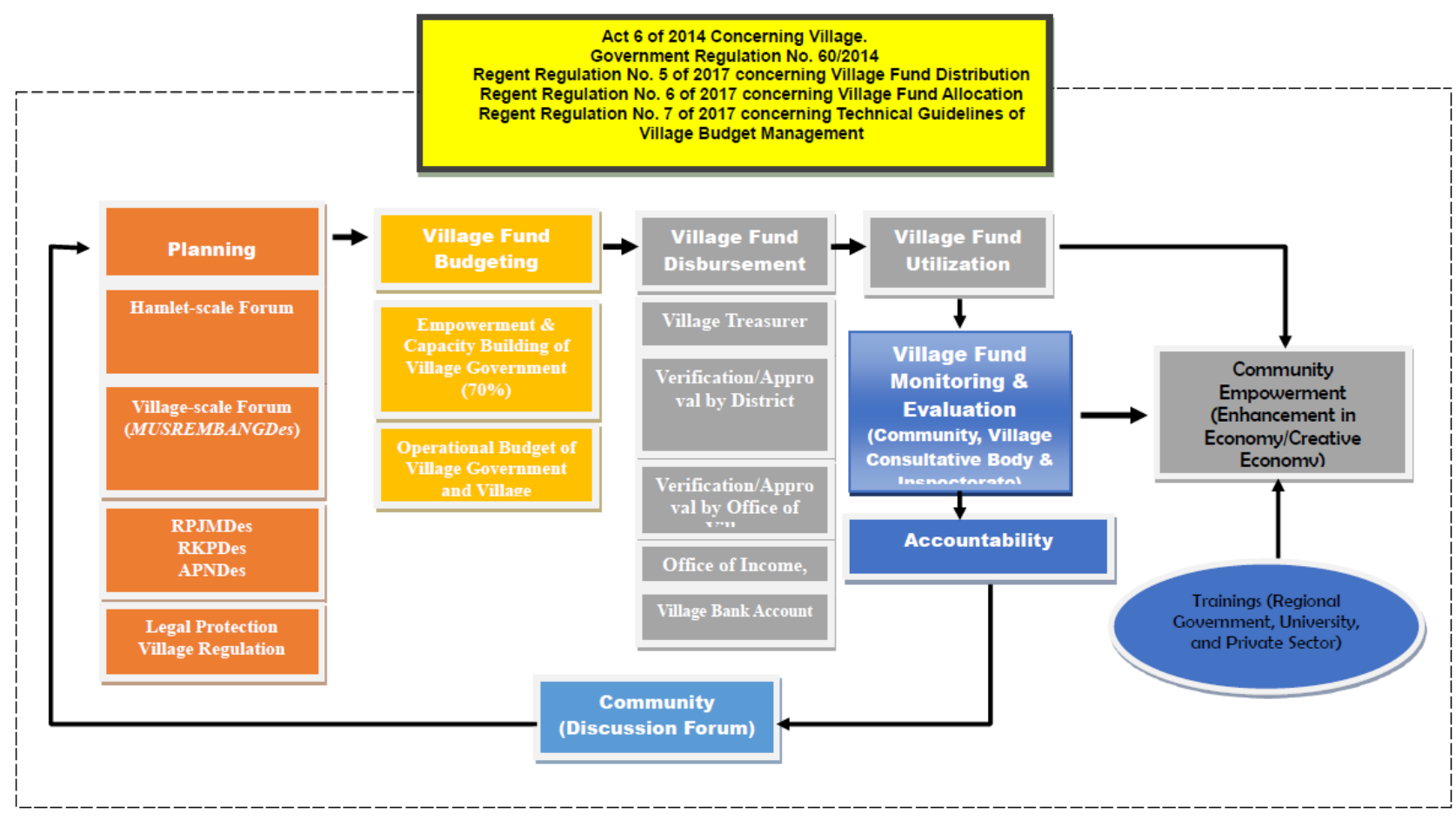

Figure 1. Model of Village Fund Management and Village Fund Allocation

\section{Conclusion}

The research findings illustrate that:

Firstly, the management pattern of the Village Fund and Village Fund Allocation is implemented optimally by most of the stakeholders in Bone Bolango regency. This complies with regulations such as Act 6 of 2014 Concerning Village, the Government Regulation No. 60/2014, the Regent Regulation No. 5 of 2017 concerning Village Fund Distribution, the Regent Regulation No. 6 of 2017 concerning Village Fund Allocation, and the Regent Regulation No. 7 concerning Technical Guidelines of Management.

Secondly, the management model proposed by this study is proven to be effective during the experiment, particularly in increasing productive economic activities. This is down to strong commitment by stakeholders, i.e., the Regional Government, academicians from university, and from the private sector.

\section{References}

Adisasmita, Rahardjo (2006). Membangun Desa Partisipasi. Graha Ilmu. Yogyakarta

Badan Pemberdayaan Masyarakat Dan Pemerintahan Desa. (2014). Pedoman umum dan petunjuk teknis pelaksanaan alokasi dana desa (ADD). Selatpanjang

Bratakusumah, Dedi Supriyadi \& Dadang Solihin. (2003). Otonomi Penyelenggaraan Pemerintah Daerah. PT. Gramedia Pustaka Utama. Jakarta

Darmiasih, dkk. (2015). Analisis Mekanisme Penyaluran Alokasi Dana Desa (ADD) ada 
Pemerintah Desa (Studi Kasus Desa Tri Buana Kecamatan Sidemen Kabupaten Karangasem).

Faridah. (2015). Transparansi dan Akuntabilitas Pemerintah Desa dalam Pengelolaan Anggaran Pendapatan dan Belanja Desa (APBDES). Sekolah Tinggi Ilmu

Jurusan Akuntansi Universitas Pendidikan Ganesha. Volume 1 No. 3 Tahun 2015.

Kartasasmita, G. (1996). Pembangunan untuk Rakyat, Memadukan Pertumbuhan dan Pemerataan. Jakarta: CIDES.

Moleong, Lexi. (2007). Metode Penelitian Kualitatif. Edisi Revisi. Cetakan Kedua Puluh Tiga. PT. Remaja Rosdakarya. Bandung

Nurcholis, Hanif. (2011). Pertumbuhan \& Penyelenggaraan Pemerintahan Desa. Jakarta: Penerbit Erlangga

Peraturan Pemerintah Republik Indonesia Nomor 60 Tahun 2014. Tentang Dana Desa Yang Bersumber Dari Anggaran Pendapatan Dan Belanja Negara

Republik Indonesia. (2005a). Peraturan Pemerintah Republik Indonesia Nomor 72 Tahun 2005, Pasal 68 ayat. Tentang Desa

Republik Indonesia. (2014b). Undang-Undang Nomor 6 Tahun 2014 Tentang Desa, Pasal 72 ayat (1) point (d), dan butir (4), op.cit, h. 41

Sahdan, Gorris dkk. (2004). Buku Saku Pedoman Alokasi Dana Desa. Bandung: FPPD.

Strauss, Anselm dan Juliet Corbin. (2009). Dasar-Dasar Penelitian Kualitatif. Cetakan Ketiga. Pustaka Pelajar. Yogyakarta.

Sugiyono. (2009). Memahami Penelitian Kualitatif, Alfabeta, Bandung

Sumaryadi, I Nyoman (2005) Perencanaan Pembangunan Daerah Otonom dan Pemberdayaan Masyarakat. Jakarta,Citra Utama.

Sutoro Eko, Anom Surya Putra, Maizir Akhmadin, Suhirman, Hadi Prayitno, Nana Suryana,

Tjokroamidjojo, Bintoro, (2000). Good Governance (Paradigma Baru Manajemen Pembangunan). UI Press, Jakarta

Wahjudin, Sumpeno. (2011). Perencanaan Desa Terpadu. Banda Aceh, Reinforcement Action and Development.

Zaini Mustakim. (2016). Dana Desa Untuk Desa Membangun Indonesia (Tanya Jawab Seputar Dana Desa). Kementerian Desa, Pembangunan Daerah Tertinggal, dan Transmigrasi Republik Indonesia. Cetakan Pertama: Jakarta

--------. (2007). Peraturan Menteri Dalam Negeri Nomor 37 Tahun 2007 Tentang Pedoman Pengelolaan Keuangan Desa, Pasal 18. 


\section{Copyright Disclaimer}

Copyright for this article is retained by the author(s), with first publication rights granted to the journal.

This is an open-access article distributed under the terms and conditions of the Creative Commons Attribution license (http://creativecommons.org/licenses/by/3.0/). 